\title{
Brain Penetrance, Receptor Occupancy and Antistress In Vivo Efficacy of a Small Molecule Corticotropin Releasing Factor Type I Receptor Selective Antagonist
}

Stephen C. Heinrichs, Ph.D., Errol B. De Souza, Ph.D., ${ }^{1}$ Gery Schulteis, Ph.D. ${ }^{2}$

Jeanette L. Lapsansky, and Dimitri E. Grigoriadis, Ph.D.

The present studies were designed to evaluate the competitive binding properties and functional effects of a novel nonpeptide $C R F_{1}$ receptor antagonist, $R 121919$. R121919 administered in doses of 0.63 to $20 \mathrm{mg} / \mathrm{kg}$ p.o. 60 min pretest in Wistar rats dose dependently attenuated the swim stress-induced anxiogenic-like behavior in the elevated plus-maze model of anxiety. Moreover, receptor autoradiography revealed that $R 121919$ dose-dependently occupied brain $C R F_{1}$ receptors in subjects tested in the plusmaze experiment. Orally administered doses of up to $20 \mathrm{mg} /$ $\mathrm{kg}$ R121919 also blunted basal and swim stress-induced pituitary-adrenocortical activation, produced additional anxiolytic-like behavioral actions in the defensive withdrawal and defensive burying paradigms, and functionally antagonized the locomotor stimulatory properties of exogenously administered CRF. Taken together, these results suggest that the anxiolytic-like efficacy of R121919 in attenuating the stress-, novelty-, shock-, and CRF-induced increases in behavioral arousal is correlated with competitive blockade of central $C R F_{1}$ receptors.

[Neuropsychopharmacology 27:194-202, 2002] (C) 2002 American College of Neuropsychopharmacology. Published by Elsevier Science Inc.
KEY WORDS: CRF; Stress; Anxiety; Pituitary-adrenal; Axiolytic

From Neurocrine Biosciences, Inc., 10555 Science Center Drive, San Diego, CA 92121.

Address correspondence to: S. C. Heinrichs, Ph.D., Department of Psychology, Boston College, McGuinn Hall, 140 Commonwealth Avenue, Chestnut Hill, MA 02467. Tel.: 617-552-0852; Fax: 617-5520523; E-mail: stephen.heinrichs@bc.edu

${ }^{1}$ Current address: Aventis Pharmaceuticals, Route 202-206, PO Box 6800, Bridgewater, NJ 08807-0800.

${ }^{2}$ Current address: UC San Diego, Department of Anesthesiology, School of Medicine, 3350 La Jolla Drive, San Diego, CA 92161-5085.

Received October 23, 2001; revised January 16, 2002; accepted January 25, 2002.

Online publication: $1 / 31 / 02$ at www.acnp.org/citations/ Npp013102236.
The widely distributed brain corticotropin-releasing factor Type $1\left(\mathrm{CRF}_{1}\right)$ receptor has been strongly implicated in the increased emotionality accompanying exposure to environmental stressors (Steckler and Holsboer 1999). First, exogenous administration of a mixed CRF receptor agonist such as CRF or urocortin in testing models of anxiety produces anxiogenic-like behavior and potentiates the effects of stressor exposure (Koob and Heinrichs 1999; Moreau et al. 1997). Second, limbic and brain stem regions thought to subserve arousal and fear-like behaviors are enriched with $\mathrm{CRF}_{1}$ receptors (Chalmers et al. 1996). Finally, $\mathrm{CRF}_{1}$ receptor knockdown (Heinrichs et al. 1997; Liebsch et al. 1999) or knockout (Smith et al. 1998; Timpl et al. 1998) produce calming, antistress effects. The putative role of $C_{2 R}$ receptor antagonists in mediating arousal, affect, and stress-induced changes in 
behavior has been further documented by several recent reports of efficacy of small molecule $\mathrm{CRF}_{1}$ receptor antagonists in testing models of anxiety and depression (Griebel et al. 1998; McCarthy et al. 1999; Millan et al. 2001; Schulz et al. 1996; Steckler and Holsboer 1999). Most recently, a Phase II clinical trial of the $\mathrm{CRF}_{1}$ receptor antagonist employed in the present studies, R121919, reported improvement in depression and anxiety scores in patients with major depression (Zobel et al. 2000). The present studies further extend this line of research by demonstrating that anti-stress behavioral actions of a $\mathrm{CRF}_{1}$ receptor antagonist occur together in time with brain $\mathrm{CRF}_{1}$ receptor occupancy (Keck et al. 2001).

The proposed rationale for potential clinical efficacy of $\mathrm{CRF}_{1}$ receptor antagonists in affective and anxiety disorders cites both pituitary-adrenocortical and behavioral symptoms of these pathologies that would be expected to respond to CRF receptor blockade (Holsboer 1999; Nemeroff 1996). Moreover, based on the diathesis-stress model of mental illness vulnerability (McEwen 2000), one could predict therapeutic efficacy of CRF receptor blockade based on antistress actions alone without necessarily postulating a role for CRF dysregulation in the etiology of affective disorders. Accordingly, the present studies document in vivo antistress, anxiolytic-like and anti-CRF efficacy of the novel $\mathrm{CRF}_{1}$ receptor antagonist, R121919, in multiple endocrine and functional models of anxiety with and without stressor exposure. Moreover, the behavioral and physiologic dependent measures employed in the present studies were chosen because of their proven sensitivity to competitive CRF receptor antagonist ligands. Thus, the goal of the present article is to validate the functional profile of action of R121919 as a novel CRF receptor ligand.

\section{MATERIALS AND METHODS}

\section{Subjects}

Subjects were male Wistar rats (Charles River, Hollister CA) weighing 240-300 g at the time of testing. Rats were housed in groups of three with ad libitum access to water and laboratory chow (Harlan Teklad, Madison, WI). Colony rooms were maintained on a reversed light cycle (1,000 off, 2,200 on), and experiments were performed in unlighted testing rooms during the nocturnal phase from 1,100 to 1,700. All testing protocols were reviewed and approved by the Institutional Animal Care and Use Committee of Neurocrine Biosciences, Inc., and were carried out in accordance with the Guide for the Care and Use of Laboratory Animals.

\section{Swim Stressor}

Forced swimming at ambient water temperatures is a stressor that activates the hypothalamo-pituitary-adre- nal axis and produces an anxiogenic-like behavioral response (Heinrichs and Koob 1998). Rats were exposed to water $\left(21-23^{\circ} \mathrm{C}\right)$ in a pool $(0.5 \mathrm{~m}$ diameter, $0.75 \mathrm{~m}$ high) for $90 \mathrm{~s}$. The animal was placed in the pool and allowed to swim or float with no means of climbing out. Following the $90 \mathrm{~s}$ period, subjects were gently lifted from the water into a dry, bath-sized terry cloth towel and dried vigorously over the entire body surface by rubbing the animal inside the towel.

\section{Elevated Plus-Maze}

The Elevated Plus-Maze is a validated (Pellow and File 1986) testing model of anxiety based on approachavoidance of brightly lit versus darkened areas of an open field environment shaped like a mathematical plus sign. The plus-maze apparatus had four arms (10 $\mathrm{cm}$ wide $\times 40 \mathrm{~cm}$ tall) constructed of opaque, black Plexiglas at right angles to each other and was elevated $50 \mathrm{~cm}$ off the floor. Two of the arms were enclosed with walls and two arms had no walls (open arms). Subjects were placed individually onto the center of the maze facing one of the closed arms and allowed free access to all four arms for $5 \mathrm{~min}$. Subjects were observed from an adjacent room through a window in the door and via an online display of the rat's location on a computer monitor. Time spent on each arm was recorded automatically by photocell beams and a computer program (note that the arm entry measure customarily reported following plus-maze testing was not recorded because of the imprecision of the photocell array in this regard). The maze was sponged clean between each trial. For the assessment of receptor occupancy, rat brains from different dose groups were removed immediately following the plus-maze observation. Receptor occupancy was therefore examined at $66.5 \mathrm{~min}$ following compound administration (60-min drug pretreatment $+90 \mathrm{~s}$ swim stress $+5 \mathrm{~min}$ on the Plus-Maze) as described below.

\section{Ex vivo CRF Receptor Autoradiography}

Brains from animals that had been administered R129191 orally, and completed the testing on the elevated Plus-maze, were removed and snap-frozen in isopentane on dry ice for $20 \mathrm{~s}$ before being transferred to dry ice for complete freezing. Tissues were then sectioned using a Hacker Cryostat, and $20-\mathrm{mm}$ sections were thaw mounted onto Fisher "plus-charged" slides (Fisher Scientific, Pittsburgh, PA), allowed to dry and stored at $-80^{\circ} \mathrm{C}$ until use. Assays were performed using standard autoradiographic protocols based on the previous characterization of $\left[{ }^{125} \mathrm{I}\right]$ sauvagine (Grigoriadis et al. 1996). On the day of assay, slides were thawed to room temperature and allowed to dry for a further 20 min. The area around each section was outlined using a grease marker, and $300 \mu l$ of $\left[{ }^{125} \mathrm{I}\right]$ sauvagine (50-100 pM 
final concentration in PBS containing $10 \mathrm{mM} \mathrm{MgCl} 2,2$ mM EGTA pH 7.0) was gently applied directly onto the section. Nonspecific binding was determined in adjacent sections with the addition of $1 \mu \mathrm{M}$ D-Phe12$\mathrm{CRF}(12-41)$ in the buffer for determination of the $\mathrm{CRF}_{1}$ and $\mathrm{CRF}_{2}$ receptor specific binding or $1 \mu \mathrm{M}$ NBI 27914, a selective $\mathrm{CRF}_{1}$ receptor antagonist, for the determination of the $\mathrm{CRF}_{1}$ specific binding. The slides were placed in a covered humidified chamber to reduce evaporation and incubated at $22^{\circ} \mathrm{C}$ for $40-45 \mathrm{~min}$. Following the incubation, the solution was gently aspirated from the section under vacuum and the slides washed using two 5-min dips in ice-cold PBS / Triton X-100 (0.01\%) pH 7.0. Slides were then air dried and apposed to Biomax MR X-ray film (Kodak, Rochester NY) for 4-5 days. Images were captured using a light box and digital camera (Northern Lights, Toronto, Canada) and imaged using the software package NIH Image (Bethesda, MD).

\section{Plasma ACTH/Corticosterone Assays}

Plasma ACTH and corticosterone levels were determined from trunk blood samples $(0.3-0.5 \mathrm{ml}$ volume $)$ collected in chilled tubes containing $2.5 \mu \mathrm{g}$ aprotinin (5000 KUI/ml). Samples were centrifuged, and plasma was removed and frozen for subsequent immunometric assay for ACTH (Allegro HS ACTH, Nichols Institute Diagnostics, San Juan Capistrano, CA) or radioimmunoassay for corticosterone (ICN Biomedicals, Cleveland, $\mathrm{OH})$ with an intraassay variability of $3.2 \%$ and an interassay variability of $7.8 \%$. Samples were collected following instantaneous decapitation from 1,300-1,700 beginning $2 \mathrm{~h}$ into the dark phase of the circadian cycle.

\section{Defensive Burying}

Defensive Burying (also know as the Shock Probe Test) is a validated (Basso et al. 1999) testing model of anxiety based on a defensive reaction to one-time exposure to a noxious stimulus. Testing occurred in a standard rat cage, with 2 inches of bedding along the bottom, and a small hole in the side 1" above the bedding (to accommodate the probe). For two days prior to testing, animals were habituated to the testing cage in their home cage groups of three. On test day, a probe connected to a Coulbourn precision shocker (model E13-01) was inserted through the hole in the cage and set to deliver 1-1.5 $\mathrm{mA}$ of shock on contact (completion of the circuit). Animals were placed in the cage individually and monitored until contact with the probe and receipt of shock were confirmed by observing contact and a startle response. After receipt of one shock, the probe was deactivated and latency and duration of the animal's burying response was measured over a 10-min test. Bedding was changed and the cage washed between each test to avoid interference from olfactory cues.

\section{Defensive Withdrawal}

Defensive Withdrawal is a validated (Takahashi et al. 1989) testing model of anxiety based on willingness/reluctance to emerge from an enclosure situated within a large arena. Testing was performed in a Plexiglas open field $(106 \times 92 \times 77 \mathrm{~cm})$ containing a cylindrical galvanized steel chamber $17 \mathrm{~cm}$ deep and $10 \mathrm{~cm}$ in diameter. The chamber was open at one end, and located along the wall of the open field aligned lengthwise and $15 \mathrm{~cm}$ away from a corner of the open field. The open field was illuminated by fluorescent ceiling lighting. For testing, the animals were introduced into the unfamiliar test environment by placing them into the small chamber. The behavior of the animals was monitored and recorded by a video tracking system (PolyTrack, San Diego Instruments, San Diego, CA). The latency to leave and total time in the chamber were recorded over a 15-min testing period.

\section{Locomotor Activity}

Locomotor activity was measured in transparent polycarbonate shoebox-housing cages with five transversely and two longitudinally mounted horizontal photocell beams (Cage Rack Activity System; San Diego Instruments). Beam interruptions were monitored continuously by a microcomputer. Rats were first habituated to the testing cages for $180 \mathrm{~min}$ one day prior to the testing day. On the testing day after a 60-min adaptation period, rats were infused with a treatment. Activity was then monitored for $180 \mathrm{~min}$ following injection. No food or water was available in the testing environment. The maximum duration of exposure to the testing environment, and hence the maximum length of food and water restriction on any given day, was four consecutive hours.

\section{Drug/Peptide}

R121919 (Neurocrine Biosciences, San Diego, CA), a novel pyrrolopyrimidine CRF Type 1 receptor antagonist, was readiliy soluble in distilled water and administered by oral gavage in a volume of $1 \mathrm{ml} / \mathrm{kg}$. Note that whereas dose ranges of R121919 administered in the various testing contexts were adjusted somewhat according to the known efficacy profile of peptide CRF receptor antagonists in each respective behavioral or physiological procedure, the single dose of $20 \mathrm{mg} / \mathrm{kg}$ was examined in each case for the purpose of comparative analysis. R121919 was administered one hour prior to testing. Rat/human [r/h] CRF(1-41) was synthesized by Nick Ling at Neurocrine Biosciences using solid phase methodology on a peptide synthesizer (Beckman Model 990). Distilled water adjusted to $\mathrm{pH} 6.7$ was used as the peptide diluent. R/h CRF was administered immediately prior to testing. 


\section{Intracerebroventricular Cannula Implantation and Injection}

For the purpose of central administration of CRF in the locomotor studies, rats were anesthetized with isoflurane $(2-5 \%$ in oxygen) and secured in a stereotaxic instrument (Kopf, Tujunga, CA). A guide cannula (Plastics One, Roanoke, VA) aimed above the lateral ventricle was then implanted and anchored to the skull with one stainless steel screw and dental cement. Stereotaxic coordinates were, with the tooth bar $+5.0 \mathrm{~mm}$ above interaural zero, $-0.6 \mathrm{~mm}$ posterior to bregma, $\pm 2.0 \mathrm{~mm}$ lateral, and $-3.2 \mathrm{~mm}$ below skull surface at the point of entry. Guide cannulae were kept patent until injection by insertion of a dummy stylet. Animals were undisturbed for a seven-day postsurgical recovery period. For injections, the dummy stylet was removed and an injector was inserted through the guide to $1 \mathrm{~mm}$ beyond its tip. Five microliters were injected over a one-minute period.

\section{Statistics}

Descriptive statistics are reported as parametric mean \pm standard error of the mean. For comparison of multiple treatment groups with a control group, factorial (between subjects) ANOVA was performed. If warranted by significant results in the overall ANOVA, post hoc, two group comparisons were performed using the Scheffé test. All studies were conducted using betweensubject designs in which naïve rats were tested only once in the respective behavioral and physiological contexts.

\section{RESULTS}

The affinity and selectivity of R121919 has been previously described (Grigoriadis et al. 2000). The in vitro data for this molecule are summarized in Table 1. R121919 has high affinity for the $\mathrm{CRF}_{1}$ receptor (approximately $5 \mathrm{nM}$ ) with very low affinity for the $\mathrm{CRF}_{2}$ receptor (data not shown). This molecule is a functional antagonist and inhibits both CRF-stimulated cAMP formation from cells expressing the human $\mathrm{CRF}_{1}$ receptor and CRF-stimulated ACTH release from cultured rat anterior pituitary cells with $\mathrm{EC}_{50}$ values of 60 and 20 $\mathrm{nM}$, respectively (Table 1 ). The selectivity and competitive nature of this compound offered the opportunity to examine the behavioral effects of $\mathrm{CRF}_{1}$ receptor blockade.

In the elevated Plus Maze, a 1-h oral pretreatment with the selective $\mathrm{CRF}_{1}$ receptor antagonist, R121919, dose-dependently attenuated the anxiogenic consequences of subsequent exposure to a swim stressor (Figure 1). An overall significant $[\mathrm{F}(4,37)=3.7, p<.02]$ reduction in the Percent Time on Open Arms measure was produced in part by a significant anxiogenic-like effect of the swim stressor relative to nonstressed controls (Schéffe test, $p<.05$ ). Rats treated with the $0.63 \mathrm{mg} / \mathrm{kg}$ po dose of R121919 also exhibited the anxiogenic-like effect relative to nonstress controls (Shéffe test, $p<$ .05), whereas rats treated with 2.5 or $20 \mathrm{mg} / \mathrm{kg}$ doses did not differ from the nonstress control group. This antistress action of R121919 is consistent with that produced by central administration of peptide CRF receptor antagonists examined in this testing context (Heinrichs et al. 1994).

Examination of ex vivo competitive binding of CRF receptors following R121919 administration in the Plus Maze experiment revealed a dose-dependent occupancy of CRF receptors by the CRF receptor antagonist (Figure 2). Figure 2A demonstrates the binding of $\left.{ }^{[25} \mathrm{I}\right]$ sauvagine in vehicle-treated animals. Note the labeling of $\mathrm{CRF}_{1}$ receptors in the cortical regions and the labeling of $\mathrm{CRF}_{2}$ receptors in the lateral septum (LS). In fact, clear labeling of the $\mathrm{CRF}_{2 \alpha}$ receptors can be observed specifically in the LS and the $C_{2 \beta}$ receptors in the choroid plexus (for a detailed description of the localization of the receptor subtypes, see Chalmers et al. 1995). As demonstrated in Figure 2, at the lowest dose tested $(0.63 \mathrm{mg} /$ $\mathrm{kg}$ ) there was no apparent inhibition of $\left[{ }^{125} \mathrm{I}\right]$ sauvagine binding, suggesting that no detectable amount of compound was occupying CRF receptors. At a dose of 2.5 $\mathrm{mg} / \mathrm{kg}$, there was an approximate $50 \%$ reduction in the amount of $\left[{ }^{125} \mathrm{I}\right]$ sauvagine binding, suggesting that R121919 was occupying receptors. At $20 \mathrm{mg} / \mathrm{kg}$, virtually all of the [125I]sauvagine labeling was absent in the frontal cortex (FC), whereas the $\mathrm{CRF}_{2}$ receptors in the

Table 1. In vitro pharmacological profile of R121919

\begin{tabular}{|c|c|}
\hline Assay & Activity $(\mathrm{nM} \pm \mathrm{SEM})$ \\
\hline \multicolumn{2}{|l|}{ Inhibition of $\left[{ }^{125} \mathrm{I}\right]$ sauvagine binding to human } \\
\hline $\mathrm{CRF}_{1}$ receptor expressing HEK293 cells & $\mathrm{Ki}=3.5 \pm 0.5 \mathrm{nM}$ \\
\hline \multicolumn{2}{|l|}{ Inhibition of CRF-stimulated cAMP production in } \\
\hline human $\mathrm{CRF}_{1}$ receptor expressing HEK293 cells & $\mathrm{EC}_{50}=60 \pm 22 \mathrm{nM}$ \\
\hline \multicolumn{2}{|l|}{ Inhibition of CRF-stimulated ACTH production } \\
\hline in cultured rat anterior pituitary cells & $\mathrm{EC}_{50}=20 \pm 8 \mathrm{nM}$ \\
\hline
\end{tabular}




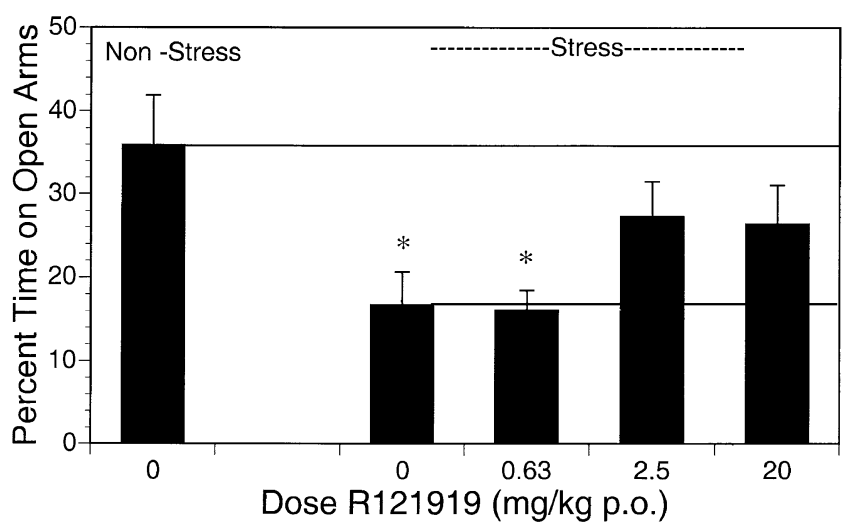

Figure 1. Antistress effect of R121919 on swim-stress induced anxiogenic behavior measured on the Elevated Plus Maze. Doses of 0, 0.63, 2.5, or $20 \mathrm{mg} / \mathrm{kg}$ R121919 were administered po. $60 \mathrm{~min}$ prior to a $90 \mathrm{~s}$ swim stressor and a 5 -min Plus Maze trial in which mean \pm SEM percent time spent on the open arms served as a the measure of anxiety. Nonstress controls were administered vehicle without subsequent exposure to the swim stressor. $\mathrm{n}=8-9 /$ group; ${ }^{*} p<.05$ relative to unstressed, vehicle-treated controls.

lateral septum and choroid plexus were not affected. Thus, R121919 appeared to selectively label $\mathrm{CRF}_{1}$ receptors as brain sites known to be enriched in $\mathrm{CRF}_{2}$ receptors such as the lateral septum were still able to bind $\left[{ }^{125} \mathrm{I}\right]$ sauvagine.

One-hour oral pretreatment with R121919 significantly reduced swim stress-induced activation of the pituitaryadrenocortical axis as measured by quantifying plasma $\mathrm{ACTH}$ and corticosterone (Figure 3). Exposure to the swim stressor elevated plasma ACTH and corticosterone as revealed by significant main effects of time $[\mathrm{F}(4,35)=63.5, p<.0001 ; \mathrm{F}(4,35)=35.9, p<.0001]$. Administration of the $20 \mathrm{mg} / \mathrm{kg}$ po dose of R121919 significantly reduced plasma ACTH and corticosterone $[\mathrm{F}(1,35)=49.7$, $p<.0001 ; \mathrm{F}(1,35)=16.1, p<.005]$, with a significant time by treatment interaction for ACTH $[\mathrm{F}(4,35)=9.7, p<$ $.0001]$ and without a significant time by treatment interaction effect for corticosterone $[\mathrm{F}(4,35)=2.4, \mathrm{~ns}]$. The 20 $\mathrm{mg} / \mathrm{kg}$ dose of R121919 significantly suppressed ACTH 10, 20, and $60 \mathrm{~min}$ after stressor application, but not at time 0 or 120, as revealed by simple main effects of dose $[\mathrm{F}(1,7)=15.1, p<.01 ; \mathrm{F}(1,7)=56.0, p<.0001$ and $\mathrm{F}(1,7)=13.2, p<.1$, respectively]. This pituitary-adrenocortical suppressing action of R121919 is consistent with that produced by intravenous administration of peptide CRF receptor antagonists examined in this testing context (Rivier et al. 1999).

Systemic pretreatment with the CRF receptor antagonist R121919 exerted a significant anxiolytic-like action on the unconditioned avoidance response measured in the Defensive Burying test. Oral administration of R121919 60 min prior to testing significantly increased the latency measured in seconds to begin burying the electrified probe $[\mathrm{F}(3,28)=3.3, p<.04]$, although no single dose was significantly different from vehicle-treated controls (Table 2). The CRF receptor antagonist also significantly decreased total time spent burying the probe $[\mathrm{F}(3,28)=8.0, p<.0005]$, with the $20 \mathrm{mg} / \mathrm{kg}$ dose producing a significant (Schéffe test, $p<.005$ ) decline relative to vehicle-treated controls (Table 2). Such results are consistent with those produced by central administration of a peptide CRF receptor antagonist in this paradigm (Korte et al. 1994).

The CRF receptor antagonist, R121919, significantly reduced Latency to Emerge and Total Time in Chamber measures in the Defensive Withdrawal paradigm. Oral administration of R121919 $60 \mathrm{~min}$ prior to testing produced an overall significant $[\mathrm{F}(4,45)=2.9, p<.04]$ reduction in latency measured in seconds to emerge although no single dose was significantly different from vehicle-treated controls (Table 3). Administration of the CRF receptor antagonist also significantly reduced total time measured in seconds spent in the chamber $[\mathrm{F}(4,45)=3.9, p<.01]$, with the 10 and $20 \mathrm{mg} / \mathrm{kg}$ po doses reaching significance (Schéffe test, p.0.05) relative to vehicle-treated controls (Table 3). These actions are consistent with those produced by central infusion of peptide CRF receptor antagonists in this context (Rodríguez de Fonseca et al. 1996).

The locomotor stimulatory action of a centrally administered dose of CRF receptor agonist peptide was dose-dependently blocked by one hour oral pretreatment with R121919 (Figure 4). An overall treatment effect on activity $[\mathrm{F}(4,25)=7.5, p<.0005]$ was produced in part by the ability of a $0.5 \mu \mathrm{g}$ icv dose of CRF administered immediately pretest to stimulate activity relative to controls not treated with CRF (Schéffe test, $p<.05$ ), and the ability of a $20 \mathrm{mg} / \mathrm{kg}$ po dose of R121919 to completely reverse this effect relative to CRF-treated controls (Schéffe test, $p<.01$ ). Such results are consistent with those employing central administration of a peptide CRF receptor antagonist in this locomotor CRFcompetition test (Menzaghi et al. 1994).

\section{CONCLUSIONS}

The present results serve to document in vivo efficacy of R121919 in a variety of rodent models of activation and emotionality. Each testing model was selected based on sensitivity to application of experimental stressors and on validated efficacy of peptide CRF receptor antagonists. In particular, efficacy of R121919 in the Plus Maze, defensive withdrawal, and defensive burying models suggests an antistress efficacy of the compound in testing models of anxiety following exposure to swim, novel environment, and electric shock stressors using normal rats. It is important to note that R121919 treatment produced both behavioral inhibition 


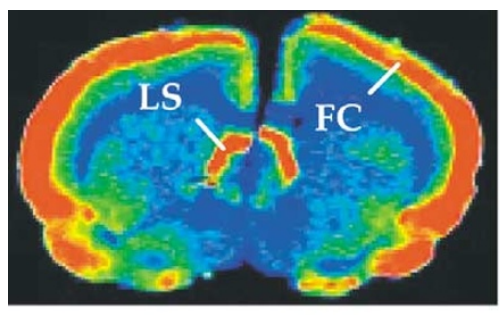

0
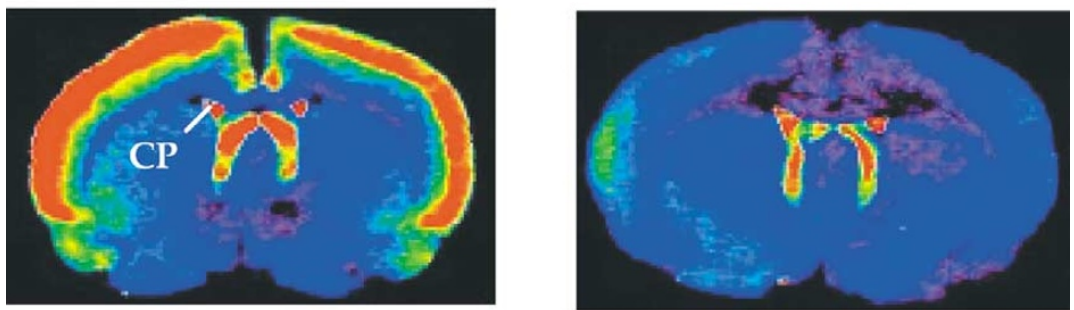

20

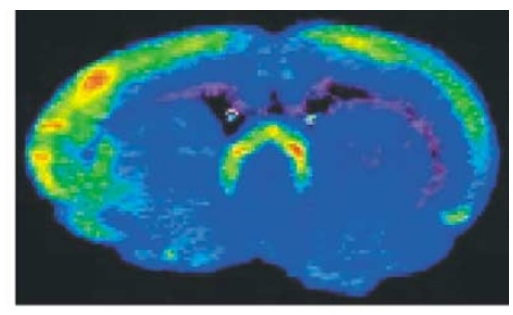

2.5

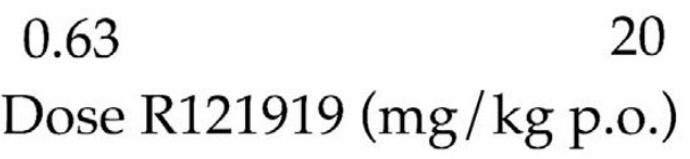

Figure 2. Dose-dependent $\mathrm{CRF}_{1}$ receptor occupancy following administration of R121919. Immediately following the 5-min Plus Maze test (Figure 1), rats treated $1 \mathrm{~h}$ previously with $0,0.63,2.5$, or $20 \mathrm{mg} / \mathrm{kg}$ doses of R121919 ( $\mathrm{n}=8-9$ /group) were sacrificed, and brains were removed for ex vivo analysis of CRF receptor occupancy using [TyrO]sauvagine binding as described in Methods section. FC, frontal cortex; LS, lateral septum; $\mathrm{CP}$, choroid plexus. in the defensive burying task and behavioral activation in the Plus Maze and defensive withdrawal tasks. This bidirectional modulatory effect of R121919 in both increasing and decreasing behavioral output is consistent with that reported for peptide, mixed receptor CRF antagonists (Koob and Heinrichs 1999) and argues against a general sedative mechanism of action for $\mathrm{CRF}_{1}$ receptor antagonism (Okuyama et al. 1999). Moreover, the ability of R121919 administration to blunt pituitaryadrenocortical tone following stressor exposure was likely exerted by $\mathrm{CRF}_{1}$ receptor blockade at the level of hypophysiotropic or pituitary binding sites. Finally, the competitive inhibition of CRF-induced locomotor activation by R121919 further suggests the CRF receptor selectivity of this compound. Perhaps the strongest support for the hypothesis that $\mathrm{CRF}_{1}$ receptor activation mediates a widespread mechanism of central nervous system activation is the finding that a $20 \mathrm{mg} / \mathrm{kg}$ oral dose of R121919 significantly blunted all five very diverse measures of activation and emotionality in the present studies.

Ex vivo examination of CRF receptor binding in subjects administered R121919 and tested on the Plus Maze revealed that the antistress behavioral effect exhibited in this testing model of anxiety was accompanied by a dose-dependent blockade of $\mathrm{CRF}_{1}$ receptors. In order to demonstrate that oral administration of R121919 can bind to $\mathrm{CRF}_{1}$ receptors and more importantly bind to the $\mathrm{CRF}_{1}$ receptor in the brain, ex vivo receptor autoradiography was performed and the receptor occupancy deter- mined indirectly through the inhibition of $\left[{ }^{125} \mathrm{I}\right]$ sauvagine. Ex vivo receptor autoradiography inherently differs from the standard receptor autoradiographic methods in that the association time of the [ $\left.{ }^{125} \mathrm{I}\right]$-Isotope must be maintained, while at the same time not allowing too much time such that the administered (competitive, reversible) compound dissociates completely in the incubation medium. Once the incubation solution is placed on the slide, compounds that have bound to their receptors in vivo on the section begin to dissociate immediately in accordance with their kinetic constants. Although a low incubation volume is used on the slide, it is critical to balance the association of the radioligand used for receptor identification and the dissociation of the ligand given in vivo once the incubation is begun on the section. These conditions were determined empirically as described in the Methods section of this article. In all cases, animals received R121919 by oral gavage and were sacrificed $65.5 \mathrm{~min}$ later following assessment on the elevated Plus Maze. In the rat, R121919 demonstrated in a dose-dependent manner the ability to penetrate into the brain and occupy CRF1 receptors in the cortex but not CRF2 $\alpha$ receptors in the lateral septum or $\mathrm{CRF}_{2 \beta}$ receptors in the choroid plexus (Figure 2). Thus at an oral dose of $20 \mathrm{mg} / \mathrm{kg}$ orally, virtually all of the $\mathrm{CRF}_{1}$ receptors in the cortex could no longer bind $\left[{ }^{125} \mathrm{I}\right]$ sauvagine, suggesting complete receptor occupancy by R121919 as defined by $\left[{ }^{125} \mathrm{I}\right]$ sauvagine binding. The $\mathrm{CRF}_{2 \alpha}$ and $\mathrm{CRF}_{2 \beta}$ receptors labeled in the same sections by $\left[{ }^{125} \mathrm{I}\right]$ sauvagine remained unaffected by the treat- 


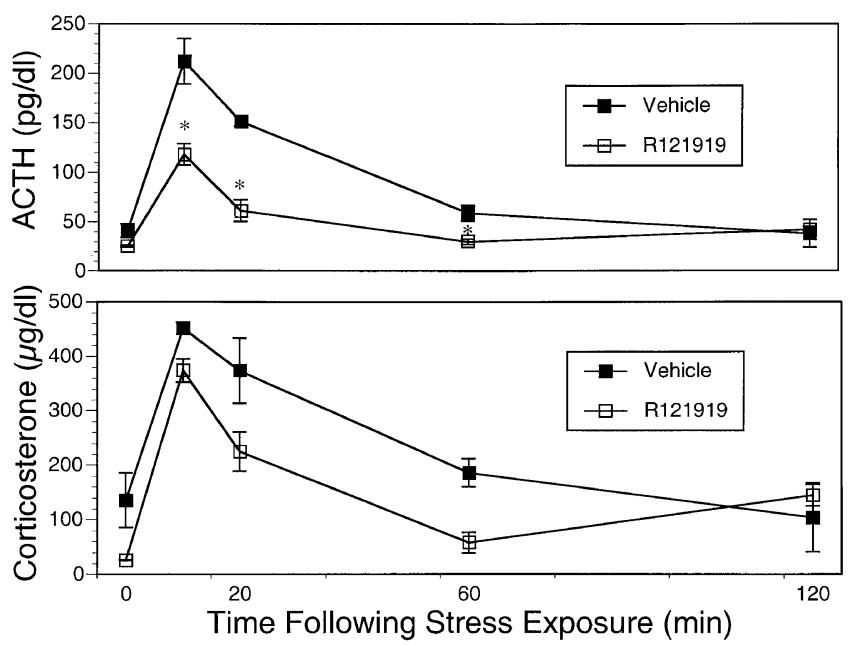

Figure 3. Administration of R121919 attenuates basal and swim stress-induced activation of the pituitary-adrenal axis. R121919 was orally administered in 0 or $20 \mathrm{mg} / \mathrm{kg}$ doses in five separate groups of rats (4-5 rats/group) $60 \mathrm{~min}$ prior to sacrifice for trunk blood collection in the case of nonstress controls (time 0 ) or 10, 20, 60, or 120 min following a 90-s swim stressor. Thus, the stressed groups were sacrificed 70,80,120, or $180 \mathrm{~min}$ following R121919 administration. The measures of pituitaryadrenal activation were mean \pm SEM plasma ACTH (top panel) and corticosterone (bottom panel), assayed subsequently in the blood samples. ${ }^{*} p<.05$ relative to vehicletreated controls.

ment, again confirming the high affinity and selectivity of the compound for the $\mathrm{CRF}_{1}$ receptor subtype.

The results described above do not establish a causal link between CRF receptor blockade and anxiolytic-like efficacy of CRF receptor antagonist treatment, but they do suggest that the two events are related. Moreover, as the receptor occupancy determinations were performed at a point in time beyond the 60 -min pretreatment interval employed for the present behavioral studies, the apparent efficacy of R121919 in occupying CRF receptors also serves to validate this aspect of the experimental design. Similarly, not all of the behavioral-dependent measures

Table 2. Anxiolytic-like Efficacy of R121919 in the Defensive Burying Test

\begin{tabular}{lcc}
\hline $\begin{array}{c}\text { Dose } \\
(\mathbf{m g} / \mathbf{k g})\end{array}$ & $\begin{array}{c}\text { Latency to } \\
\text { Begin Burying (s) }\end{array}$ & $\begin{array}{c}\text { Duration of } \\
\text { Probe Burying (s) }\end{array}$ \\
\hline 0 & $115 \pm 25$ & $135 \pm 25$ \\
5 & $100 \pm 15$ & $130 \pm 15$ \\
10 & $150 \pm 20$ & $70 \pm 20$ \\
20 & $200 \pm 30$ & $30 \pm 10$ \\
\hline
\end{tabular}

Data reflect the latency in seconds from insertion of the rat into the cage prior to initiation of burying of the electrified shock probe and total duration of probe burying in the Defensive Burying Test. Rats (8/group) were administered vehicle or 5-20 mg/ $\mathrm{kg}$ oral doses of R121919 60-minutes pretest.
Table 3. Anxiolytic-like Efficacy of R121919 in the Defensive Withdrawal Test

\begin{tabular}{lcc}
\hline $\begin{array}{c}\text { Dose } \\
(\mathbf{m g} / \mathbf{k g})\end{array}$ & $\begin{array}{c}\text { Latency to } \\
\text { Emerge (s) }\end{array}$ & $\begin{array}{c}\text { Total Time } \\
\text { in Chamber (s) }\end{array}$ \\
\hline 0 & $211 \pm 15$ & $121 \pm 28$ \\
0.63 & $149 \pm 17$ & $44 \pm 13$ \\
2.5 & $202 \pm 24$ & $58 \pm 30$ \\
10 & $157 \pm 12$ & $26 \pm 14$ \\
20 & $127 \pm 23$ & $32 \pm 15$ \\
\hline
\end{tabular}

Data reflect the latency in seconds from insertion of the rat into the testing arena to departure from the cylindrical enclosure and total time spent in the chamber during the Defensive Withdrawal Test. Rats (8-17/ group) were administered vehicle or $0.63-20 \mathrm{mg} / \mathrm{kg}$ oral doses of R121919 60-minutes pretest.

employed in the present studies (e.g., Plus Maze, defensive withdrawal) exhibited orderly, monotonic dose response curves (Keck et al. 2001), and this may hamper future efforts to establish a causal link between CRF receptor occupancy and behavioral stress reactivity.

The putative role of $\mathrm{CRF}_{1}$ receptors in mediating arousal, affect, and stress-induced changes in behavior has been further documented by several recent reports describing efficacy of small molecule $\mathrm{CRF}_{1}$ receptor antagonists in testing models of anxiety and depression (McCarthy et al. 1999; Steckler and Holsboer 1999). In particular, the nonpeptidic $\mathrm{CRF}_{1}$ antagonist CP-154,526 is reported to exert anxiolytic-like activity in the elevated Plus Maze test in rats (Lundkvist et al. 1996) to blunt physical signs of morphine withdrawal (Iredale et al. 2000) and to attenuate fear-potentiated startle (Schulz et al. 1996). A nonpeptide $C_{R F}$ receptor antagonist, CRA1000, is reported to attenuate stress-induced shortening of pentobarbital hypnosis (Arai et al. 1998) and to reverse the anxiogenic-like effect of a swim stressor on

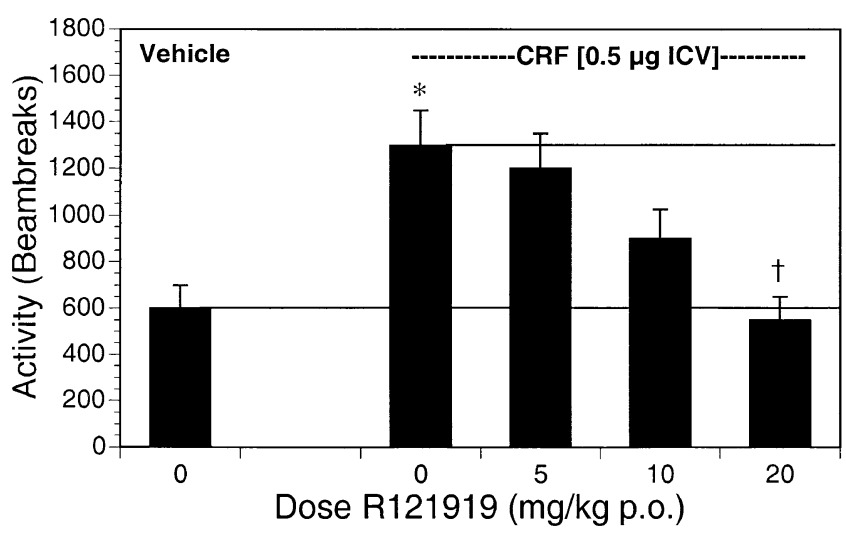

Figure 4. R121919 reverses CRF-induced locomotor activity. Mean + SEM locomotor activity counts measured over 60 min immediately following central administration of vehicle or $\mathrm{r} / \mathrm{h} \mathrm{CRF}(1-41)$ in rats orally administered vehicle or R121919 $60 \mathrm{~min}$ prior to CRF infusion. $\mathrm{n}=6$ /group, ${ }^{*} p<.05$ relative to vehicle/vehicle group, ${ }^{\dagger} p<.05$ relative to CRF/vehicle group. 
exploratory behavior (Okuyama et al. 1999). Other studies (Griebel et al. 1998) have compared the behavioral effects of CP-154,526 with those of diazepam and the 5-HT1A receptor partial agonist, Buspirone, in classic testing models of anxiety. In a mouse defense test battery which has been validated for the screening of anxiolytic drugs, CP-154,526 affected all defensive behaviors, with the exception of one risk assessment measure (Griebel et al. 1998). In mice the anxiolytic-like efficacy of CP-154,526 was judged superior to that of the atypical anxiolytic buspirone but was less robust in terms of the magnitude of the effects and the number of indices of anxiety affected than that of diazepam (Griebel et al. 1998). Potential antidepressant-like effects of CP-154,526 have also been studied (Mansbach et al. 1997), using the learned helplessness procedure, a putative model of depression with documented sensitivity to antidepressant drugs. These data support evidence implicating stress systems in the pathophysiology of depression and together with clinical evidence of pituitaryadrenocortical hyperactivation in affective disorders, provide a rationale for potential efficacy of small molecule CRF Type I receptor antagonists in the treatment of affective or anxiety-related disorders (Holsboer 1999).

\section{ACKNOWLEDGMENTS}

We thank Marge Lorang for expert technical assistance.

\section{REFERENCES}

Arai K, Ohata H, Shibasaki T (1998): Non-peptidic corticotropin-releasing hormone receptor type 1 antagonist reverses restraint stress-induced shortening of sodium pentobarbital-induced sleeping time of rats: evidence that an increase in arousal induced by stress is mediated through CRH receptor type 1. Neurosci Lett 25:103-106

Basso AM, Spina M, Rivier J, Vale W, Koob GF (1999): Corticotropin-releasing factor antagonist attenuates the "anxiogenic-like" effect in the defensive burying paradigm but not in the elevated plus-maze following chronic cocaine in rats. Psychopharmacol. 145:21-30

Chalmers DT, Lovenberg TW, De Souza EB (1995): Localization of novel corticotropin-releasing factor receptor (CRF2) mRNA expression to specific subcortical nuclei in rat brain: comparison with CRF1 receptor mRNA expression. J Neurosci 15(10):6340-6350

Chalmers DT, Lovenberg TW, Grigoriadis DE, Behan DP, De Souza EB (1996): Corticotropin-releasing factor receptors: from molecular biology to drug design. Trends Pharmacol Sci 17:166-172

Griebel G, Perrault G, Sanger DJ (1998): Characterization of the behavioral profile of the non-peptide CRF receptor antagonist CP-154,526 in anxiety models in rodents. Psychopharmacol. 138:55-66

Grigoriadis DE, Liu X-J, Vaughn J, et al. (1996): 125I-Tyr0-Sau- vagine: a novel high affinity radioligand for the pharmacological and biochemical study of human corticotropinreleasing factor $2 \alpha$ receptors. Mol Pharmacol 50:679-686

Grigoriadis DE, Chen C, Wilcoxen K, Chen T, Lorang MT, Bozigion H, Lia X-J, Ling N, McCarthy JR, De Souza EB, Vale WW (2000): In vitro characterization of R121919: a novel non-peptide corticotropin-releasing factor1 (CRF1) receptor antagonist for the potential treatment of depression and anxiety-related disorders. Society for Neuroscience. Abstracts 807:4-9

Heinrichs SC, Koob GF (1998): Application of experimental stressors in laboratory rodents. In: Crawley JN, Gerfen CR, McKay R, Rogawski MA, Sibley DR, Skolnick P (eds), Current Protocols in Neuroscience, vol. 1. New York: John Wiley \& Sons

Heinrichs SC, Lapsansky J, Lovenberg TW, De Souza EB, Chalmers DT (1997): Corticotropin-releasing factor CRF1, but not CRF2, receptors mediate anxiogenic-like behavior. Regul Pept 71:15-21

Heinrichs SC, Menzaghi F, Merlo Pich E, Baldwin HA, Rassnick S, Britton KT, Koob GF (1994): Anti-stress action of a corticotropin-releasing factor antagonist on behavioral reactivity to stressors of varying type and intensity. Neuropsychopharmalcology 11:179-186

Holsboer F (1999): The rationale for corticotropin-releasing hormone receptor (CRH-R) antagonists to treat depression and anxiety. J Psychiatr Res 33:181-214

Iredale PA, Alvaro JD, Lee Y, Terwilliger R, Chen YL, Duman RS (2000): Role of corticotropin-releasing factor receptor-1 in opiate withdrawal. J Neurochem 74:199-208

Keck ME, Welt T, Wigger A, Renner U, Engelmann M, Holsboer F, Landgraf R (2001): The anxiolytic effect of the $\mathrm{CRH}(1)$ receptor antagonist R121919 depends on innate emotionality in rats. Eur J Neurosci 13(2):373-380

Koob GF, Heinrichs SC (1999): A role for corticotropin releasing factor and urocortin in behavioral responses to stressors. Brain Res 848:141-152

Korte SM, Korte-Bouws GAH, Gohus B, Koob GF (1994): Effect of corticotropin-releasing factor antagonist on behavioral and neuroendocrine responses during exposure to defensive burying paradigm in rats. Physiol Behav 56:115-120

Liebsch G, Landgraf R, Engelmann M, Loerscher P, Holsboer $F$ (1999): Differential behavioural effects of chronic infusion of CRH 1 and CRH 2 receptor antisense oligonucleotides into the rat brain. J Psychiatr Res 33:153-163

Lundkvist J, Chai Z, Teheranian R, Hasanran H, Bartfai T, Jenck F, Widmer U, Moreau JL (1996): A non-peptidic corticotropin releasing factor receptor antagonist attenuates fever and exhibits anxiolytic-like activity. Eur J Pharmacol 309:195-200

Mansbach RS, Brooks EN, Chen YL (1997): Antidepressantlike effects of CP-154,526, a selective CRF1 receptor antagonist. Eur J Pharmacol 323:21-26

McCarthy JR, Heinrichs SC, Grigoriadis DE (1999): Recent advances with the CRF1 receptor: design of small molecule inhibitors, receptor subtypes and clinical indications. Curr Pharm Des 5:247-273

McEwen BS (2000): Allostasis and allostatic load: implications for neuropsychopharmacology. Neuropsychopharmalcol. 22:108-124 
Menzaghi F, Howard RL, Heinrichs SC, Vale W, Rivier J, Koob GF (1994): Characterization of a novel and potent corticotropin-releasing factor antagonist in rats. J Pharmacol Exp Ther 269:564-572

Millan MJ, Brocco M, Gobert A, Dorey G, Casara P, Dekeyne A (2001): Anxiolytic properties of the selective, non-peptidergic CRF(1) antagonists, CP154,526 and DMP695: a comparison to other classes of anxiolytic agent. Neuropsychopharmacol. 4:585-600

Moreau J-L, Kilpatrick G, Jenck F (1997): Urocortin, a novel neuropeptide with anxiogenic-like properties. Neuroreport 8:1697-1701

Nemeroff CB (1996): The corticotropin-releasing factor (CRF) hypothesis of depression: new findings and new directions. Mol. Psychiat. 1:336-342

Okuyama S, Chaki S, Kawashima N, Sazoki Y, Ogawa S, Nakazato A, Kumagai T, Okubo T, Tomisawa K (1999): Receptor binding, behavioral, and electrophysiological profiles of nonpeptide corticotropin-releasing factor subtype 1 receptor antagonists CRA1000 and CRA1001. J Pharmacol Exp Ther 289:926-935

Pellow S, File SE (1986): Anxiolytic and anxiogenic drug effects on exploratory activity in an elevated plus-maze: a novel test of anxiety in the rat. Pharmacol Biochem Behav 24:525-529

Rivier JE, Kirby DA, Lahrichi SL, Corrigan A, Vale WW, Rivier CL (1999): Constrained corticotropin releasing factor antagonists (astressin analogues) with long duration of action in the rat. J Med Chem 42:3175-3182

Rodríguez de Fonseca F, Rubio P, Menzaghi F, Mertopick E, Rivier J, Koob GF, Novarro M (1996): Corticotropinreleasing factor (CRF) antagonist [D-Phe 12, NLE21,38,
CalphaMeLeu37] CRF attenuates the acute actions of the highly potent cannabinoid receptor agonist HU-210 on defensive-withdrawal behavior in rats. J Pharmacol Exp Ther 276:56-64

Schulz DW, Mansbach RS, Sprouse J, Braselton JP, Collins J, Corman M, Dunaiskis A, Faraci S, Schmidt AW, Seeger T, Seymour P, Tingley FD 3rd, Winston EN, Chen YL, Hey MJ (1996): CP-154,526: A potent and selective nonpeptide antagonist of corticotropin releasing factor receptors. Proc. Natl. Acad. Sci. USA 93:10477-10482

Smith GW, Aubry J-M, Dellu F, Contarino A, Bilezikjian LM, Gold LH, Chen R, Marchuk Y, Hauser C, Bentley CA, Sawchenko PE, Koob GF, Vale W, Lee KF (1998): Corticotropin releasing factor receptor 1-deficient mice display decreased anxiety, impaired stress response, and aberrant neuroendocrine development. Neuron 20:1093-1102

Steckler T, Holsboer F (1999): Corticotropin-releasing hormone receptor subtypes and emotion. Biol Psychiatry 46:14801508

Takahashi LK, Kalin NH, Vandenburgt JA, Sherman JE (1989): Corticotropin-releasing factor modulates defensivewithdrawal and exploratory behavior in rats. Behav Neurosci 103:648-654

Timpl P, Spanagel R, Sillaber I, Kresse A, Real JM, Stalla GK, Blanquer V, Steckler T, Holsboer F, Wurst W (1998): Impaired stress response and reduced anxiety in mice lacking a functional corticotropin-releasing hormone receptor. Nat Genet 19:162-166

Zobel AW, Nickel T, Kuenzel HE, Ackl N, Sonntag A, Ising M, Holsboer F (2000): Effects of the high-affinity corticotropin-releasing hormone receptor 1 antagonist R121919 in major depression: the first 20 patients treated. J Psychiatr Res 34:171-181 